\title{
Genetic techniques inform conservation aquaculture of the endangered Kootenai River white sturgeon Acipenser transmontanus
}

\author{
A. Drauch Schreier ${ }^{1, *}$, J. Rodzen ${ }^{2}$, S. Ireland ${ }^{3}$, B. May ${ }^{1}$ \\ ${ }^{1}$ Department of Animal Science, University of California Davis, Davis, California 95616, USA \\ ${ }^{2}$ Sacramento County District Attorney, Forensic Services Laboratory, Sacramento, California 95820, USA \\ ${ }^{3}$ Kootenai Tribe of Idaho, Bonners Ferry, Idaho 83805, USA
}

\begin{abstract}
Large river-resident and diadromous fishes are globally threatened by environmental degradation, overharvest, and a rapidly changing climate. Conservation aquaculture is a tool that, used in concert with ecological restoration and harvest regulation, can protect the unique genetic, morphological, and behavioral characteristics of imperiled populations. Although conservation aquaculture programs are designed to minimize genetic impacts on wild populations, founder effects, domestication, and inbreeding may occur. Genetic monitoring may be used in the context of adaptive management to reduce deleterious genetic impacts of captive breeding in wild populations. Here we use the conservation aquaculture program for the endangered Kootenai River white sturgeon Acipenser transmontanus as a case study to illustrate how genetic tools might improve captive breeding programs for large river fishes. We used microsatellite markers to reveal very low levels of genetic diversity in the Kootenai River white sturgeon relative to other populations across the species' range. We show that by using high numbers of broodstock, the conservation aquaculture program has captured $96 \%$ of the population's microsatellite diversity in hatchery-released progeny in only $10 \mathrm{yr}$. We validate the power of parentage analysis to identify family relationships between individual white sturgeon using a panel of 18 microsatellite loci. Parentage analysis will become crucial for inbreeding avoidance in the Kootenai River white sturgeon aquaculture program in 2020 to 2030 , when the majority of broodstock available for captive breeding will originate from the hatchery.
\end{abstract}

KEY WORDS: White sturgeon $\cdot$ Conservation aquaculture $\cdot$ Genetic monitoring $\cdot$ Microsatellite markers Resale or republication not permitted without written consent of the publisher

\section{INTRODUCTION}

River fishes worldwide are threatened by habitat fragmentation and loss, modification of natural flow regimes, pollution, loss of habitat connectivity due to impoundment, invasive species, and overharvest (Jelks et al. 2008). Although restoration of habitat and reduction or elimination of harvest are the best means to recover vulnerable fish populations, lack of available personnel, political will, and/or funding make these actions time consuming and difficult to implement. In addition, the current imperiled status of many fish populations often is the result of many interrelated environmental and demographic changes that have occurred over time. It may be difficult to pinpoint the most limiting factor(s) on which to focus management action for population restoration. One conservation tool that might be used in concert with the identification of limiting factors and ecological restoration is conservation aquaculture. 
Conservation aquaculture is the use of captive propagation to sustain imperiled species or populations and preserve local characteristics in the face of severe declines. Although similar to supplementation programs in that hatchery releases occur into pre-existing natural populations, the goals of conservation and traditional supplementation hatcheries are quite different. Traditional supplementation hatcheries primarily seek to increase the abundance of target populations, often to enhance fisheries or attain related fisheries management goals, while in conservation aquaculture programs, the preservation of unique genetic diversity, phenotypes, and behaviors is of ultimate concern (Anders 1998, H. Kincaid unpubl.). Conservation aquaculture programs might be seen as a 'stopgap' measure to slow population decline while restoration activities to alleviate conditions limiting natural recovery are underway (Ireland et al. 2002a,b). Traditional supplementation hatcheries, however, are often viewed as mitigation for the effects of environmental decline in and of themselves. Special techniques to minimize genetic changes in the hatchery environment are particularly emphasized in conservation aquaculture programs to minimize changes to the natural population as well as to maximize survival of captive-bred progeny.

Hatchery-induced genetic changes may include domestication, founder effects, and inbreeding. Domestication occurs through intentional or unintentional human-mediated selection or the relaxation of the natural selective regime in the hatchery environment (Waples 1999). Decreasing egg sizes in a chinook salmon Oncorhynchus tshawytscha hatchery program (Heath et al. 2003) and decreasing reproductive success of steelhead $O$. mykiss with increasing numbers of generations in captivity (Araki et al. 2007a) provide examples of how modified selection regimes may reduce fitness in the wild. A founder effect is a reduction in genetic diversity in the natural population that can occur if only small numbers of broodstock are used in captive breeding. Low levels of genetic diversity may reduce a population's ability to adapt to environmental challenges (Lacy 1997). Inbreeding, or the mating of close relatives, may occur in small, broodstock-limited populations and can result in inbreeding depression. Inbreeding depression reduces the fitness of inbred individuals, limiting their ability to contribute surviving offspring to future generations.

Although it is inevitable that captive breeding will induce some genetic changes in natural populations (Waples 1999), genetic tools can be used in the adaptive management of conservation aquaculture programs to minimize these changes. Genetic monitoring allows managers to characterize baseline levels of genetic diversity in a target population which can be used to evaluate genetic diversity loss as a result of the conservation aquaculture program. Broodstock numbers, mating schemes, and release strategies can then be adaptively modified to minimize genetic diversity loss. Multilocus genotypes can be used as 'genetic tags' to track broodstock used in the hatchery and re-released into the wild. Relatedness analyses (Kozfkay et al. 2008) or parentage assignment (this study) can be used to prevent mating close relatives when pedigree information is limited, thus reducing the likelihood of inbreeding depression.

From a genetic perspective, large fishes are particularly suited for conservation aquaculture due to their long generation time and iteroparity. Species with lengthy generation times can retain genetic diversity for long periods, even in the face of severe demographic declines (Quattro et al. 2002, Lippé et al. 2006, Lawrence et al. 2008, Moyer et al. 2009). Imperiled populations of large river-resident or diadromous fishes may still possess moderate to high levels of genetic diversity which can be preserved by conservation aquaculture programs utilizing sufficient numbers of broodstock. Iteroparity ensures that an individual receives multiple chances to pass genetic material to the next generation, slowing genetic diversity loss. Multi-year stocking programs using unique wildcaptured broodstock each year have been shown to reduce founder effects traditionally associated with hatchery programs (Heggenes et al. 2006, Drauch \& Rhodes 2007, Rourke et al. 2009, 2010).

Here we describe how genetic tools have been used to guide a conservation aquaculture program for an endangered population of the white sturgeon Acipenser transmontanus. The white sturgeon is considered the largest freshwater fish species in North America, currently inhabiting major river systems along the West Coast from the Sacramento River, California (USA), to the Fraser River, British Columbia (Canada). Although land-locked populations confirm that white sturgeon can complete their life cycle in fresh water, white sturgeon inhabiting the lower portions of river systems regularly use estuary and coastal habitat, suggesting they are more accurately classified as diadromous (Parsley et al. 2008). Like all North American sturgeon species, white sturgeon were subject to severe harvest pressure at the turn of the 20th century for the caviar fishery, which led to significant population declines across the spe- 
cies' range. White sturgeon are currently listed as endangered under the Species at Risk Act in Canada, and a distinct population segment of white sturgeon in the Kootenai River has been listed as endangered by the US Fish and Wildlife Service (USFWS).

A tributary of the Columbia River, the Kootenai River (spelled Kootenay in Canada) runs through British Columbia and the US states of Montana and Idaho (Fig. 1). Kootenai River white sturgeon inhabit the river reach between Kootenai Falls and Bonnington Falls (Duke et al. 1999). Bonnington Falls has acted as a natural barrier isolating Kootenai River white sturgeon from other Columbia River populations for 10000 to $12000 \mathrm{yr}$ (Northcote 1973). The Kootenai River white sturgeon population has exhibited declines in abundance since the 1960s and almost no recruitment since 1974 (Duke et al. 1999, Paragamian et al. 2005), although natural spawning events have been observed (Ireland et al. 2002b). The population currently consists of $\sim 1000$ individuals, primarily aging adults (R. Beamesderfer et al. unpubl.). Numerous limiting factors have contributed to the decline of Kootenai River white sturgeon including Libby Dam, which was completed in 1975 (Duke et al. 1999). Located 42 river km upstream of Kootenai Falls, Libby Dam has reduced downstream productivity in the Kootenai River system and has decreased spring flows by $50 \%$ and increased winter flows by $300 \%$ (Duke et al. 1999). Other factors contributing to white sturgeon decline are diking and channelization of the Kootenai River between Bonners Ferry and Kootenay Lake, agricultural development of the river valley, and decreases in water quality from mining and industry (Duke et al. 1999; Paragamian et al. 2005).

On 6 September 1994, the Kootenai River white sturgeon population was listed as endangered by the USFWS. One component of the recovery plan for this species was to implement conservation aquaculture to sustain the population until habitat restoration could re-establish natural recruitment. Before white sturgeon were formally listed, the Kootenai Tribe of Idaho examined the feasibility of a conservation aquaculture program and made experimental releases of a small number of hatcheryreared juveniles in 1990 (Ireland et al. 2002b). Success of their initial efforts led to the establishment of the Kootenai Tribe of Idaho (hereafter Tribe) white sturgeon conservation aquaculture program (CAP), which began large-scale releases in 1999. Each year, fisheries managers from the Tribe collect male and female broodstock from the Kootenai River, spawn them in the Tribal hatchery, and return them to the river. The target number of females spawned each year is 12 , and often up to 20 male broodstock are captured and spawned annually (C. Lewandowski pers. comm.). While most females are mated with multiple males, each male is mated with only a single female. Crosses are performed in a $1 \times 1$ fashion, with no mixing of milt from multiple males, and full sibling families are reared in separate circular tanks. Some families are reared at the Tribal hatch-
Fig. 1. Acipenser transmontanus. Range of white sturgeon in the Kootenai/y River Basin. Map courtesy of R. Beamesderfer 
ery while others are transported to the Kootenay Trout Hatchery in British Columbia, as a failsafe measure against disease or equipment failure. Variance in reproductive success among females is common, and family sizes are variable at release. Over the duration of the Tribe's CAP, captive-born white sturgeon have been released from the hatcheries anywhere from the fertilized egg stage to 16-18 mo old, with recent releases at older ages due to the discovery of densitydependent competition among age-0 individuals post release (Justice et al. 2009).

Goals of the Tribe's CAP include restoration of a natural age and size structure to the Kootenai River population and maintenance of genetic diversity until habitat restoration allows natural recruitment to resume (Ireland et al. 2002b). A genetic management plan developed for the CAP called for genetic monitoring of the program to prevent genetic diversity loss and avoid inbreeding depression (H. Kincaid unpubl.). In the early 2000s, microsatellite loci were developed for genetic monitoring of Kootenai River white sturgeon (Rodzen \& May 2002). Although these neutral loci have no adaptive significance, they can be used as monitoring tools to detect negative genetic changes induced by the CAP, such as founder effects, which may reduce the effective population size, $\mathrm{N}_{\mathrm{e}}$ of the wild population. Components of genetic monitoring included (1) characterizing levels of genetic diversity in the Kootenai River population (J. Rodzen et al. unpubl., this paper), (2) documenting the amount of genetic diversity represented by Kootenai River broodstock, and (3) using parentage analysis to design mating schemes when most broodstock available to the hatchery will be of captive origin (projected to occur in 2020-2030; Paragamian et al. 2005, R. Beamesderfer et al. unpubl.). In this paper, we used genetic monitoring of the Tribe's CAP as a case study of how genetic tools might be applied to conservation aquaculture of other vulnerable river-resident and diadromous fish populations. We present a characterization of neutral genetic diversity in this endangered population and an assessment of how this genetic diversity is being preserved by the Tribe's CAP. We also describe the validation of microsatellite mark- ers for parentage analysis in hatchery families of known parentage, as parentage analysis to describe family relationships between putative broodstock will become necessary to prevent inbreeding in later years of the program.

\section{MATERIALS AND METHODS}

\section{Sampling and DNA extraction}

For genetic monitoring components 1 and 2, DNA was extracted from adult white sturgeon samples $(\mathrm{N}=376)$ from the Kootenai River using a Gentra PureGene extraction kit. The sample included adults randomly sampled in the Kootenai River $(\mathrm{N}=201)$ and those used as broodstock in the Tribe's CAP since $2002(\mathrm{~N}=175)$. Only those individuals spawned in the hatchery that produced surviving offspring are classified as broodstock for genetic monitoring purposes. To validate parentage assignment accuracy, DNA was extracted from 23 to 24 young of the year from each of 11 families ( $\mathrm{N}=261$ ) belonging to the 2010 year class reared by the Tribe.

Table 1. Acipenser transmontanus. Microsatellites used for genetic monitoring and parentage assignment in the Kootenai Tribe's conservation aquaculture program for white sturgeon. TD1 and TD2 refer to touchdown thermal profiles. The first step of TD1 contains an annealing temperature $\left(\mathrm{T}_{\mathrm{A}}\right)$ decrease $\left(\mathrm{T}_{\mathrm{A}}=65^{\circ} \mathrm{C}\right.$ to $\left.\mathrm{T}_{\mathrm{A}}=58^{\circ} \mathrm{C},-0.5^{\circ} \mathrm{C} \mathrm{cycle}^{-1}\right)$, and the second step has a constant $\mathrm{T}_{\mathrm{A}}$ $\left(54^{\circ} \mathrm{C}\right)$. Both steps of TD2 contain $\mathrm{T}_{\mathrm{A}}$ decreases: (1) $\mathrm{T}_{\mathrm{A}}=68^{\circ} \mathrm{C}$ to $58^{\circ} \mathrm{C},-2^{\circ} \mathrm{C}$ cycle $^{-1}$, and (2) $\mathrm{T}_{\mathrm{A}}=58^{\circ} \mathrm{C}$ to $50^{\circ} \mathrm{C},-2^{\circ} \mathrm{C} \mathrm{cycle}^{-1}$

\begin{tabular}{|lcccc|}
\hline Microsatellite & $\begin{array}{c}\mathrm{MgCl}_{2} \\
(\mathrm{mM})\end{array}$ & $\begin{array}{c}\mathrm{T}_{\mathrm{A}} \\
\left({ }^{\circ} \mathrm{C}\right)\end{array}$ & $\begin{array}{c}\text { Annealing } \\
\text { time (s) }\end{array}$ & Source \\
\hline Atr 105 & 1.6 & TD1 & 60,60 & Rodzen \& May (2002) \\
Atr 107 & 1.6 & TD1 & 60,60 & Rodzen \& May (2002) \\
Atr 109 & 2.1 & TD1 & 60,60 & Rodzen \& May (2002) \\
Atr 117 & 3.1 & TD1 & 60,60 & Rodzen \& May (2002) \\
Atr 1101 & 1.8 & 57 & 30 & Rodzen \& May (2002) \\
Atr 1173 & 1.3 & TD1 & 60,60 & Rodzen \& May (2002) \\
As015 & 2.5 & 56 & 30 & Zhu et al. (2005) \\
AciG 2 & 1.5 & 60 & 30 & Börk et al. (2008) \\
AciG 35 & 3.0 & 56 & 30 & Börk et al. (2008) \\
AciG 43 & 2.0 & 56 & 30 & GenBank: HM459582 \\
AciG 52 & 2.0 & 56 & 105 & Börk et al. (2008) \\
AciG 53 & 2.0 & 56 & 105 & Börk et al. (2008) \\
AciG 110 & 2.0 & 56 & 30 & Börk et al. (2008) \\
AciG 140 & 2.5 & 56 & 30 & Börk et al. (2008) \\
AciG 46 & 2.0 & TD2 & 300, 120 & Börk et al. (2008) \\
AciG 51 & 2.0 & TD2 & 300,120 & Börk et al. (2008) \\
AciG 61 & 2.0 & TD2 & 300, 120 & Börk et al. (2008) \\
AciG 203 & 2.0 & TD2 & 300,120 & Börk et al. (2008) \\
a Forward primer sequence: TAA TAC AGC GGG GAT GGA A & \\
reverse primer sequence: GCA CAG TGA AAG CAC GGT AA & \\
\hline
\end{tabular}




\section{Microsatellite genotyping}

Adult samples for genetic monitoring were genotyped at 14 microsatellite loci (Table 1). Broodstock and young of the year from the 2010 year class were genotyped at these 14 loci and 4 additional microsatellite loci specifically optimized to increase the power of parentage analysis (AciG 46, AciG 51, AciG 61, AciG 203; Drauch Schreier et al. 2011). PCR conditions for Atr loci are published elsewhere (Rodzen \& May 2002). As015, AciG 2, AciG 35, AciG 43, AciG 52, AciG 53, AciG 110, and AciG 140 were amplified in reactions containing $\sim 10 \mathrm{ng}$ DNA, $1.0 \mu \mathrm{l}$ of $10 \times$ reaction buffer, $0.2 \mathrm{mM}$ of each dNTP (Promega), 1.5 to $3.0 \mathrm{mM} \mathrm{MgCl}_{2}, 5.0 \mu \mathrm{M}$ each of forward (labeled) and reverse (unlabeled) primers, 0.375 U Taq polymerase (Promega GoTaq), and $\mathrm{dH}_{2} \mathrm{O}$ to a volume of $10 \mu \mathrm{l}$. PCR reactions for AciG 46, 51, 61, and 203 were performed in a $10 \mu \mathrm{l}$ total volume containing $\sim 10 \mathrm{ng} \mathrm{DNA}, 1.0 \mu \mathrm{l}$ of $1 \times$ PCR reaction buffer with $\mathrm{MgCl}_{2}$ mix (Roche), $0.2 \mathrm{mM}$ of each dNTP, $0.2 \mu \mathrm{M}$ of each forward and reverse primer, $0.04 \mu \mathrm{M}$ of M13 universal tailed primer, and $0.75 \mathrm{U}$ of FastStart Taq DNA polymerase (Roche).

PCR product $(1.0 \mu \mathrm{l})$ was added to $9.0 \mu \mathrm{l}$ of highly deionized formamide and $0.2 \mu \mathrm{l}$ of either Liz 600 (AciG 46, 51, 61, and 203) or Rox 400HD (all other loci) size standards. Fragment analysis was conducted on an Applied Biosystems (ABI) 3730xl Genetic Analyzer, and allele scoring was completed in ABI GeneMapper v4.0 software. White sturgeon are an octoploid derived species with microsatellites detected in 4 or 8 copies (Drauch Schreier et al. 2011). As it was impossible to determine the number of copies of each microsatellite allele in this complex genome, we were unable to obtain codominant genotypes. Instead, each microsatellite allele was scored as a present/ absent dominant locus, creating a binary phenotype of $1 \mathrm{~s}$ and $0 \mathrm{~s}$ for each individual (Rodzen \& May 2002, Israel et al. 2009, Drauch Schreier et al. 2011, Pfeiffer et al. 2011).

\section{Genetic monitoring}

Before any genetic analyses were conducted, the program GenoType (Meirmans \& Tienderen 2004) was used to identify duplicate samples in the large genetic dataset we maintain for the Kootenai River. Preliminary quality control tests with 95 white sturgeon samples collected throughout the species' range genotyped at 14 loci revealed an allelic dropout rate of $1.2 \%$ (A. Drauch Schreier unpubl. data); therefore, 2 mismatches were allowed between putative duplicate samples. Fourteen pairs of samples were found to be identical, and 1 multilocus genotype from each pair was removed to avoid any bias in genetic diversity analyses. The first task of genetic monitoring was to characterize levels of genetic diversity in the Kootenai River population as a whole. The total number of microsatellite alleles across 14 loci in the Kootenai River adult samples was calculated in the program GenAlEx vers. 6.3 (Peakall \& Smouse 2006). We also wished to compare levels of genetic diversity in the endangered Kootenai River population to those in other white sturgeon populations across the species' range. We subsampled 100 adults from the Kootenai River dataset and compared genetic diversity levels in the Kootenai River to those in populations from the lower Columbia River below Bonneville Dam $\left(\mathrm{LCR}_{i} \mathrm{~N}=98\right)$, the upper Columbia River above Grand Coulee Dam (UCR; N = 101), and the Sacramento River $(\mathrm{N}=101)$. GenAlEx was used to calculate the total number of alleles and number of private alleles in each population. Although a traditional measure of heterozygosity cannot be estimated in the polyploid species, we used the average number of alleles per individual per locus as a proxy for heterozygosity. We compared the average number of alleles per individual per locus at each locus among populations using a KruskalWallis test (VassarStats). For loci at which significant differences were detected, we used the Dunn test (VassarStats; Dunn 1964, Zar 1999) to make pairwise comparisons between the Kootenai River and each other population.

The second task of genetic monitoring was to determine whether the Tribe's CAP was adequately representing Kootenai River genetic diversity in each year class. We initially examined the pool of broodstock used in each year $(2002,2004$ to 2010) separately. Tissue samples from 2003 broodstock were unavailable for analysis. Treating each annual broodstock pool as a different 'population,' we used GenAlEx to calculate the total number of alleles detected in each pool and compared these values to the number of alleles detected in the total population. To determine the cumulative amount of genetic diversity captured by the Tribe's CAP, we calculated the number of alleles detected across all broodstock (2002, 2004 to 2010) and compared this value to the total number of alleles detected in the Kootenai River population. 


\section{Parentage analysis}

The log-likelihood (LOD) method of Gerber et al. (2000) was implemented in the program Parent.exe (Rodzen et al. 2004) to assign parentage to offspring of the 11 full-sibling families of known parentage containing 23 to 24 individuals each. All 18 microsatellite loci were used for parentage analysis, and only 2010 male and female broodstock were included as possible parents in the analysis. To calculate LOD scores, we took the log of the likelihood that individual $\mathrm{X}$ is the parent of offspring $\mathrm{A}$ and divided it by the likelihood that individual $\mathrm{X}$ and offspring $\mathrm{A}$ are unrelated (Gerber et al. 2000). LOD scores were then summed across all loci. An individual was first assigned to the most likely sire and then to the most likely dam. To evaluate the significance of such assignments, the statistic delta $(\delta)$ was employed to evaluate how much more likely the 'best' parent was to be the true parent than was the 'second best' parent identified (Marshall et al. 1998). Delta is simply the difference of the LOD scores between the most likely and second most likely parent of a given offspring. For example, a $\delta$ of 3 for a certain possible parent means that particular animal was $10^{3}(=1000)$ times more likely to be the true parent than the second most likely possible parent. Parentage analysis accuracy was assessed for both sires and dams with and without implementing the $\delta$ criterion.

\section{RESULTS}

\section{Genetic monitoring}

In total, 97 alleles at 14 microsatellite loci were detected in the Kootenai River white sturgeon population. Comparison of genetic diversity among white sturgeon populations revealed over twice as much genetic diversity in the LCR, UCR, and Sacramento River populations compared to an equal sized subsample from the Kootenai River population (Fig. 2). No private alleles were detected in the Kootenai River population, although 16, 9, and 26 were observed in the LCR, UCR, and Sacramento rivers, respectively (Fig. 2).

A Kruskal-Wallis test to compare the mean number of alleles per individual per locus, a proxy for heterozygosity in this high-order polyploid, revealed significant differences among populations at all but one locus (AciG 2; Table 2). A Dunn's test using the Kootenai River as a 'control' to which all other populations were compared revealed that the Kootenai
River population had significantly fewer alleles per individual per locus than the other populations at 11 of 14 loci (Table 2). At loci Atr 105 and Atr 1101, the Kootenai River population had significantly fewer alleles per individual per locus than 1 and 2 other populations, respectively (Table 2).

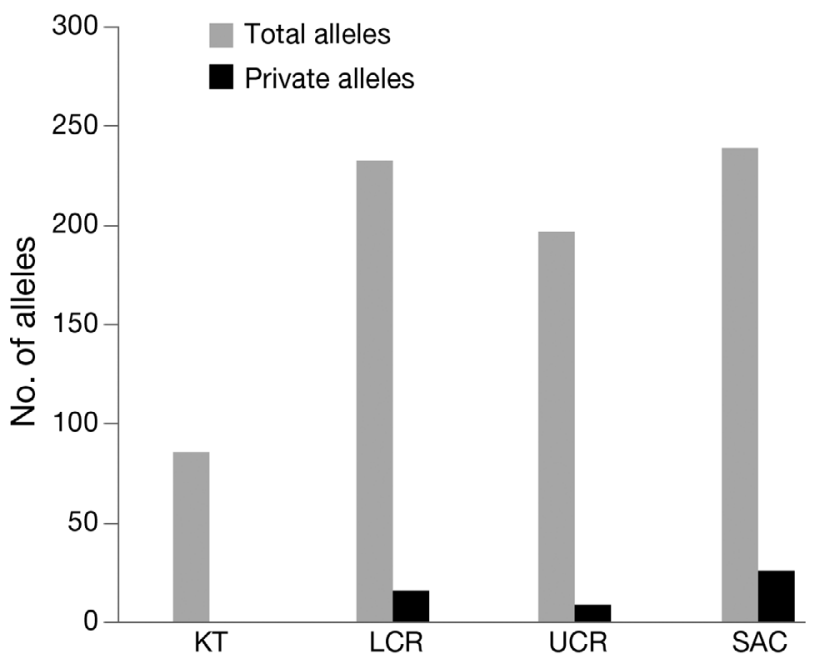

Fig. 2. Acipenser transmontanus. Total number of alleles and private alleles detected in a subsample of the Kootenai River dataset $(K T ; N=100)$ and samples collected from the Lower Columbia River (LCR; $N=98)$, Upper Columbia River

$\left(\mathrm{UCR}_{i} \mathrm{~N}=100\right)$, and Sacramento River $\left(\mathrm{SAC}_{i} \mathrm{~N}=101\right)$

Table 2. Acipenser transmontanus. Average number of alleles per individual per locus in the Kootenai River (KT), Lower Columbia River (LCR), Upper Columbia River (UCR), and Sacramento River (SAC). p values are from a KruskalWallis test indicating significant differences among groups. Asterisks indicate where the number of alleles per individual per locus is significantly lower than LCR, UCR, and SAC using Dunn's test $(\mathrm{p}=0.05)$

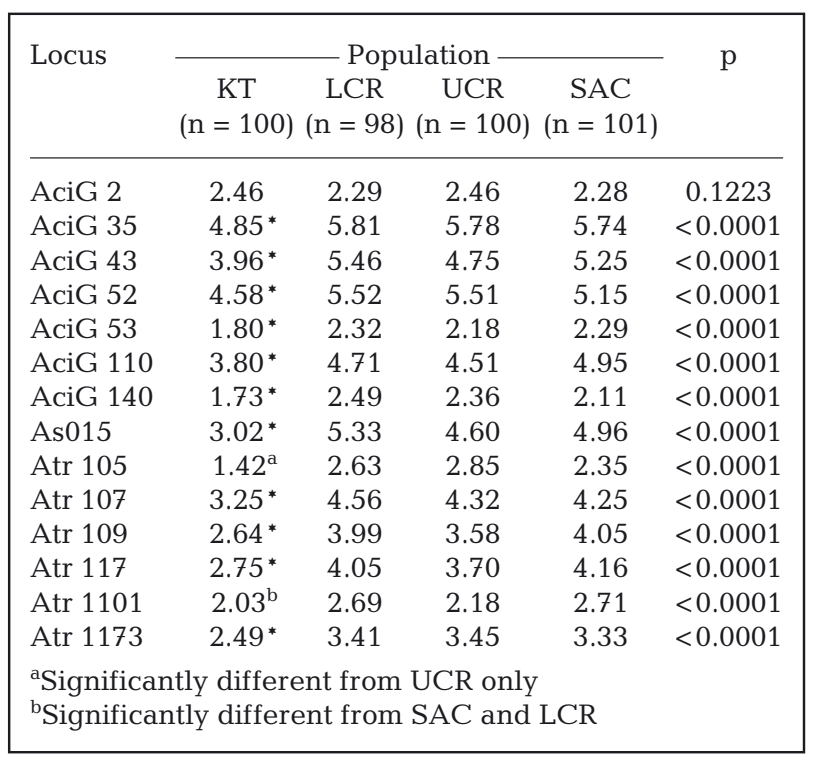




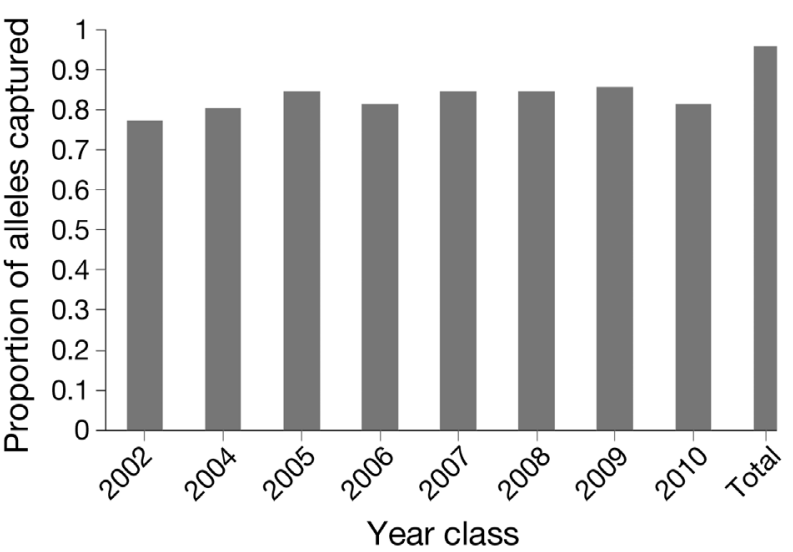

Fig. 3. Acipenser transmontanus. Proportion of Kootenai River population microsatellite alleles represented by the Kootenai Tribe's conservation aquaculture program broodstock from 2002 and 2004 to 2010. 'Total' refers to the proportion of population alleles that were captured by broodstock over all years of the program for which genetic monitoring was conducted

When single Tribe CAP brood years are considered, between 75 and 83 out of 97 alleles are detected each year (Fig. 3). When the genetic diversity represented in CAP broodstock was considered cumulatively across brood years 2002 and 2004 to 2010, 93 alleles detected in the population were represented in the broodstock. Assuming each broodstock cross produces offspring that survive after release, $96 \%$ of genetic diversity remaining in the Kootenai River population has been propagated in the Tribe's CAP.

\section{Parentage analysis}

Parentage assignment in the 2010 year class achieved high levels of success, with 70.8 to $100 \%$ of individuals assigned to the correct sire and dam across 11 families (overall $92.8 \%$ to correct sire and $91.1 \%$ to correct dam) without using the $\delta$ criterion (Table 3). Assignments in families KT-D128 and KT6 FB7 were complicated by a missing genetic sample from dam KT-38E5, and the sire for family KT-523F was unknown. Tabulation of the numbers of successful assignments did not consider assignments to dams in families KT-D128 or KT-6FB7 or to the sire in KT-38E5. Assignment success tended to be higher in families where genetic samples from both parents were available.

A distribution of $\delta$ values for correct and incorrect assignments was plotted (Fig. 4), and a threshold $\delta$ value of 2.5 was selected for parentage analysis.
Although somewhat subjective, we selected this value to minimize the number of incorrect assignments while maximizing the number of correct assignments possible. An assignment made with $\delta$ of $\geq 2.5$ indicates that the 'best' parent is at least 316 times $\left(10^{2.5}\right)$ more likely to be the true parent than the second 'best' parent. When the $\delta$ criterion of confidence was utilized as a threshold for making assignments, overall accuracy increased with 28 incorrect assignments being eliminated. Only 6 incorrect

Table 3. Acipenser transmontanus. Parentage assignment accuracy using 24 possible parents of the 2010 year class and 18 microsatellite loci (including additional loci AciG 46, AciG 51, AciG 61, and AciG 201). The proportion of individuals assigned correctly to each parent with and without the $\delta$ criterion (see 'Materials and methods') is shown. Numbers in parentheses are the numbers of offspring assigned to the correct parent but with a $\delta$ value below the threshold. NA: No genetic sample from dam KT-38E5 was available and sire is unknown; U: sire is unknown

\begin{tabular}{|lcccc|}
\hline Family & $\begin{array}{c}\text { Assignments with } \delta \\
\text { Correct } \\
\text { sire }\end{array}$ & $\begin{array}{c}\text { Correct } \\
\text { dam }\end{array}$ & $\begin{array}{c}\text { Assignments } \\
\text { Correct } \\
\text { sire }\end{array}$ & $\begin{array}{c}\text { Correct } \\
\text { dam }\end{array}$ \\
\hline KT-D128 & $24 / 24$ & NA & $24 / 24(0)$ & NA \\
KT-6FB7 & $19 / 24$ & NA & $12 / 24(7)$ & NA \\
KT-OC72 & $24 / 24$ & $24 / 24$ & $23 / 24(1)$ & $24 / 24(0)$ \\
KT-6CD2 & $22 / 23$ & $22 / 23$ & $19 / 23(3)$ & $18 / 23(4)$ \\
KT-3F5C & $22 / 24$ & $23 / 24$ & $18 / 24(4)$ & $19 / 24(4)$ \\
KT-6F60 & $22 / 23$ & $22 / 23$ & $20 / 23(3)$ & $23 / 23(0)$ \\
KT-54D0 & $21 / 24$ & $24 / 24$ & $17 / 24(4)$ & $21 / 24(3)$ \\
KT-E401 & $23 / 23$ & $17 / 23$ & $19 / 23(4)$ & $14 / 23(3)$ \\
KT-1193 & $24 / 24$ & $22 / 24$ & $24 / 24(0)$ & $21 / 22(1)$ \\
KT-523F & $\mathrm{U}$ & $17 / 24$ & $\mathrm{U}$ & $9 / 17(8)$ \\
KT-8749 & $20 / 24$ & $24 / 24$ & $16 / 24(4)$ & $22 / 24(2)$ \\
\hline
\end{tabular}

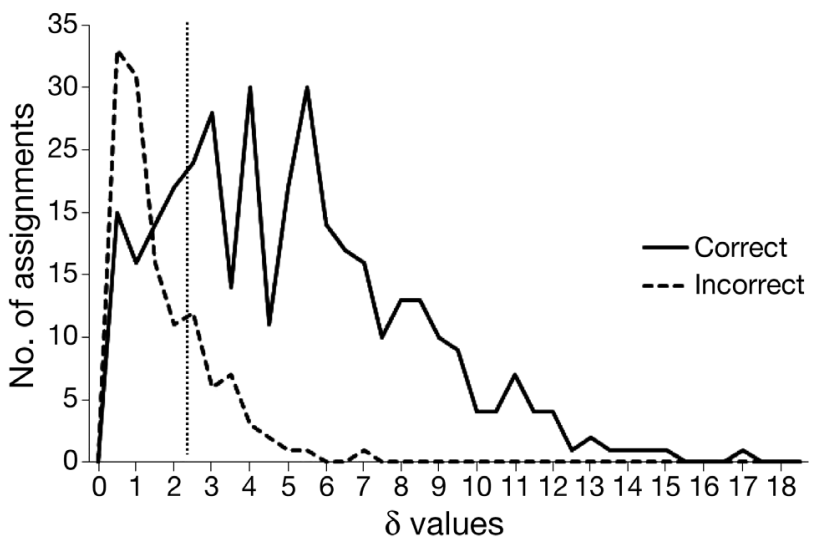

Fig. 4. Acipenser transmontanus. Distribution of $\delta$ values (see 'Materials and methods') for correct and incorrect assignments in the Kootenai Tribe's conservation aquaculture program 2010 year class. Vertical dotted line indicates the selected $\delta$ value of 2.5 
assignments were made with the $\delta$ threshold of 2.5 , compared to 34 without implementing the $\delta$ criterion. However, 29 assignments to the correct sire and 25 to the correct dam did not meet the $\delta$ criterion of confidence (Table 3).

\section{DISCUSSION}

The very low levels of microsatellite genetic diversity in Kootenai River white sturgeon reported here corroborate previous work using different genetic markers. Initial examinations of genetic diversity in white sturgeon with allozyme markers discovered few polymorphic loci and lower levels of heterozygosity in Kootenai River white sturgeon relative to other populations examined (Bartley et al. 1985, A. Setter \& E. Brannon unpubl.). Examination of mitochondrial DNA control region sequences found only 2 haplotypes in the Kootenai River while other populations possessed 4 to 11 haplotypes (Anders 2002). A more recent phylogeographic study detected only 1 haplotype in the Kootenai River while other populations possessed 4 to 15 haplotypes (B. Mahardja pers. comm.).

There are several possible explanations for such low levels of genetic diversity in the Kootenai River population, none of which is mutually exclusive. First, the Kootenai River Valley was glaciated during the Pleistocene, and the Kootenai River was recolonized by what was likely a small number of white sturgeon founders. Significantly lower numbers of alleles per individual per locus, a proxy for heterozygosity, in the Kootenai River population relative to other white sturgeon populations further supports a founder effect and subsequent inbreeding. Furthermore, Bonnington Falls has acted as a downstream barrier to fish movement in the Kootenai River for 10000 to 12000 yr (Northcote 1973), isolating Kootenai River white sturgeon from gene flow from conspecific populations in the Columbia and Snake Rivers. Finally, more recent demographic declines due to harvest and ecological disturbances coupled with several decades of recruitment failure have likely contributed to genetic diversity loss via genetic drift (Anders et al. 2002).

Nonetheless, genetic monitoring indicates that the Tribe's CAP is adequately preserving the neutral genetic diversity that remains in the Kootenai River population. As microsatellites are generally neutral markers (Jarne \& Lagoda 1996), we used them here only to track hatchery-induced genetic and demographic changes that may have deleterious effects on a natural population. Loss of neutral genetic diversity due to founder effects may reflect a decrease in $\mathrm{N}_{\mathrm{e}}$ and a loss of alleles of adaptive significance, which would reduce a population's ability to adapt to environmental changes over time. Representing as many adults as possible in the CAP maximizes the $\mathrm{N}_{\mathrm{e}}$ and increases the possibility of preserving all adaptive genetic variants extant in the Kootenai River population. When broodstock genotypes are examined cumulatively, they contain nearly all alleles detected in white sturgeon adults at large in the Kootenai River. This study did not consider the contributions of 51 broodstock used in early experimental releases by the Tribe's CAP in 1990 to 1998 (Ireland et al. 2002a) from which genetic samples were not archived. Therefore, the proportion of genetic diversity represented by the hatchery program reported here should be considered a minimum estimate.

To date, genetic data have been collected from 369 unique Kootenai River adults, which represent $~ 30 \%$ of the population at large by recent estimates (R. Beamesderfer et al. unpubl.). Although it is possible that we have not yet detected some rare alleles in the population, continued capture of novel broodstock increases the likelihood that unsampled genetic diversity will be represented in future years of the program. As the Tribe's CAP has only been conducting large-scale releases for about a decade (half of a sturgeon generation), it is likely that a large majority of extant Kootenai River white sturgeon genetic diversity will be propagated by the program within a single generation.

Despite low levels of genetic diversity, we show that accurate parentage analysis is possible in the Kootenai River population when using 18 microsatellite loci. Previous validation experiments using fewer loci examined the feasibility of accurate parentage assignment in the Kootenai River population. J. Rodzen et al. (unpubl.) had difficulty resolving correct parentage relationships using only 8 microsatellite loci. A. Drauch et al. (unpubl.) found higher levels of assignment accuracy with 14 loci, but few assignments were possible when the $\delta$ criterion was applied. Increasing the parentage panel to 18 microsatellite loci has provided high levels of assignment accuracy similar to those achieved by A. Drauch et al. (unpubl.) as well as an increase in the number of assignments possible using the $\delta$ criterion. With the 14-marker panel, hatchery managers may have had to weigh the costs and benefits of accepting assignments not meeting the $\delta$ criterion of confidence in years when few broodstock were available. The most risk-averse mating scheme would exclude individuals for which parentage could 
not be resolved with confidence to reduce the chance of accidentally mating close relatives. However, additional power from increasing the marker panel to 18 loci has reduced this concern by increasing the proportion of assignments that meet the $\delta$ criterion. Implementing the $\delta$ criterion in the 18-marker panel has also alleviated concerns about the proportion of misassignments, as misidentifying close relatives as unrelated individuals could lead to inbreeding in the CAP. Only 6 of 452 assignments were made to an incorrect parent when implementing the $\delta$ criterion with the 18-marker panel.

Parentage analysis will become a crucial component of genetic management in the Tribe's CAP in the early 2020s, when it is predicted that the majority of adults at large in the Kootenai River will have been born in captivity (R. Beamesderfer et al. unpubl.). There also exists the potential for parent-offspring mating in a long-lived species such as white sturgeon. As the Tribe has archived tissue from nearly all hatchery broodstock since the initiation of large-scale releases, we will be able to use parentage analysis and the broodstock genotype archive to determine the familial relationships among captive-born adults brought into the hatchery. Knowledge of familial relationships will allow hatchery personnel to avoid crosses between parents and offspring, full siblings, and half siblings, which is essential in a population that already exhibits a low level of genetic diversity.

Genetic markers might also be used to genetically 'tag' all wild adults handled by hatchery personnel. Tag loss has been reported in shortnose sturgeon Acipenser brevirostrum marking programs, and a $\sim 6 \%$ rate of tag non-detection (either due to tag shedding or the failure of scanners to detect tags) has been observed in adult Kootenai River white sturgeon by Tribal fisheries personnel and state fisheries managers (Smith et al. 2002, D. Wakkinen pers. comm.). Genetic tags provide the most accurate way to track the use of broodstock in the hatchery and prevent multiple spawning of the same individual. The maintenance of a broodstock genetic archive can allow for 'family tagging' of hatchery-reared progeny too small for insertion of individual identification tags. Parentage assignment can identify the family from which an individual originated, which may be used in future studies examining family-specific variance in survival of stocked individuals (Rourke et al. 2009). Field assessments have shown that average survival in the first year after stocking is $27 \%$, and increases to an average of $84 \%$ and near $100 \%$ at ages 2 and 3, respectively (Justice et al. 2009). Evaluating how much genetic diversity survives the age-1 post-stocking bottleneck will provide the most accurate assessment of genetic diversity loss in the Kootenai River population, as we are unable to estimate effective population size, $\mathrm{N}_{\mathrm{e}}$, using the dominant microsatellite dataset.

In addition to the genetic monitoring described above, genetic data can be implemented in other ways to inform CAPs for large river-resident and diadromous fishes. If genetic samples are available from the wild population before the initiation of stocking, a comparison of genetic diversity levels and partitioning of genetic variation in the historical and contemporary populations can allow one to evaluate genetic changes due to stocking events (e.g. Rourke et al. 2010). Genetic data also might be used to estimate the number of broodstock required to represent a target percentage of genetic diversity in hatcheryreared progeny. J. Rodzen et al. (unpubl.) used a resampling analysis to show that 80 to $90 \%$ of Kootenai River genetic diversity at 8 microsatellite loci could be represented by 30 to 40 broodstock. This information may be used to predict how long a conservation aquaculture program may need to operate to achieve program goals. For example, if it is estimated that 200 broodstock are required to adequately represent a population's genetic diversity, the necessary duration of a conservation aquaculture program can be estimated by the predicted availability of broodstock in each year.

This study has focused on the use of neutral genetic markers to inform hatchery programs, as less is known about changes to adaptive genetic diversity in captivity which might occur through domestication. Chebanov et al. (2002) described how selection of early-spawning females for a hatchery program for Azov Sea stellate Acipenser stellatus and Russian sturgeon A. gueldenstaedtii has reduced the temporal extent of spawning in the wild populations in the course of just 15 yr. However, various hatchery practices might be adopted to reduce the risk of domestication, such as the random selection of different wildborn adults as broodstock each year and equalizing family sizes to reduce overrepresentation of individuals better adapted to captive conditions (Araki et al. 2007b, Frankham 2008). The Tribe's CAP reduces domestication risks by randomly sampling wild broodstock from many locations in the Kootenai River throughout several months leading up to the spawning season. The program also avoids representing the same individuals in multiple brood years; only a single female broodstock has been spawned more than once in the 12 yr that the large-scale CAP has been in operation. 
The identity and magnitude of selective pressures driving adaptation to captivity are difficult to quantify and likely will vary in different captive breeding programs (Allendorf et al. 2010). Similarly, adaptation to similar selective pressures may differ among populations of the same species due to differences in genomic architecture (Frankham 2008). Advances in the burgeoning field of conservation genomics may provide the capability to monitor conservation aquaculture programs for changes in allele frequency at multiple adaptive genes throughout the genome (Allendorf et al. 2010).

Although there are still some uncertainties surrounding the long-term effects of conservation aquaculture that should be addressed by future research, this technique remains an important tool for the conservation of large river-resident and diadromous fishes. When deciding whether to implement a CAP for an imperiled population, it is important to consider the alternative to reproductive intervention. In a critically endangered population such as the Kootenai River white sturgeon, choosing not to implement a CAP risks continued decline in population size and such consequences as irreversible genetic diversity loss, lowered reproduction and survival due to Allee effects, and an increased likelihood that a stochastic event(s) may lead to extinction (Anders 1998, Ireland et al. 2002a). By preserving local genetic diversity and preventing further population size declines, the benefits of conservation aquaculture may outweigh the risks, particularly when negative side effects are minimized through careful planning and genetic monitoring.

Acknowledgements. Funding for genetic monitoring of the Kootenai Tribe white sturgeon conservation aquaculture program was provided by the Bonneville Power Administration and the Kootenai Tribe of Idaho (BPA Project 198806400 - Contract no. 30729). Research was carried out under a Section 10 permit from the United States Fish and Wildlife Service (no. TE798744-7). We thank C. Lewandowski, J. Siple, and the Kootenai Tribal Hatchery staff for help with sample collection and for providing additional information about the conservation aquaculture program. D. Wakkinen provided information on the prevalence of tag non-detection in Kootenai River adult white sturgeon. Thanks also to B. Mahardja and A. Weakley for assistance in data collection over the years. The quality of this manuscript was improved by helpful comments from A. Squier, B. Erickson, D. Gille, and 2 anonymous reviewers.

\section{LITERATURE CITED}

Allendorf FW, Hohenlohe PA, Luikart G (2010) Genomics and the future of conservation genetics. Nat Rev Genet 11:697-709
Anders PJ (1998) Conservation aquaculture and endangered species: Can objective science prevail over risk anxiety? Fisheries 23:28-31

Anders PJ (2002) Population structure and mitochondrial DNA diversity of North American white sturgeon (Acipenser transmontanus): an empirical expansive gene flow model. PhD dissertation, University of Idaho, Moscow, ID

Anders PJ, Richards DL, Powell MS (2002) The first endangered white sturgeon population: repercussions in an altered large-river floodplain ecosystem. In: Van Winkle W, Anders P, Secor DH, Dixon D (eds) Biology, management, and protection of North American sturgeon. Proc 28th Am Fish Soc Symp. American Fisheries Society, Bethesda, MD, p 67-82

Araki H, Cooper B, Blouin MS (2007a) Genetic effects of captive breeding cause a rapid, cumulative fitness decline in the wild. Science 318:100-103

Araki H, Ardren WR, Olsen E, Cooper B, Blouin MS (2007b) Reproductive success of captive-bred steelhead trout in the wild: evaluation of three hatchery programs in the Hood River. Conserv Biol 21:181-190

Bartley DM, Gall GAE, Bentley B (1985) Preliminary description of the genetic structure of white sturgeon, Acipenser transmontanus, in the Pacific Northwest. In: Binkowski FP, Doroshov SI (eds) North American sturgeons: biology and aquaculture potential. Dr. W. Junk, Dordrecht, p 105-109

Börk KB, Drauch AM, Israel JA, Pedroia JK, Rodzen J, May BP (2008) Development of new microsatellite DNA primers for green and white sturgeon. Conserv Genet 9: 973-979

> Chebanov MS, Karnaukhov GI, Galich EV, Chmir YN (2002) Hatchery stock enhancement and conservation of sturgeons, with an emphasis on the Azov Sea populations. J Appl Ichthyol 18:463-469

> Drauch AM, Rhodes OE Jr (2007) Genetic evaluation of the lake sturgeon reintroduction program in the Mississippi and Missouri Rivers. N Am J Fish Manag 27:434-442

Drauch Schreier A, Gille DA, Mahardja B, May B (2011) Neutral markers confirm the octoploid origin and reveal spontaneous polyploidy in white sturgeon, Acipenser transmontanus. J Appl Ichthyol 27(Suppl 2):24-33

Duke S, Anders P, Ennis G, Hallock R and others (1999) Recovery plan for Kootenai River white sturgeon (Acipenser transmontanus). J Appl Ichthyol 15:157-163

> Dunn OJ (1964) Multiple contrasts using rank sums. Technometrics 6:241-252

Frankham R (2008) Genetic adaptation to captivity in species conservation programs. Mol Ecol 17:325-333

Gerber S, Mariette S, Streiff R, Bondénès C, Kremer A (2000) Comparison of microsatellites and amplified fragment length polymorphism markers for parentage analysis. Mol Ecol 9:1037-1048

> Heath DD, Heath JW, Bryden CA, Johnson RM, Fox CJ (2003) Rapid evolution of egg size in captive salmon. Science 299:1738-1740

> Heggenes J, Beere M, Tamkee P, Taylor EB (2006) Genetic diversity in steelhead before and after conservation hatchery operation in a coastal, boreal river. Trans Am Fish Soc 135:251-267

Ireland SC, Anders PJ, Siple JT (2002a) Conservation aquaculture: an adaptive approach to prevent extinction of an endangered white sturgeon population. In: Van Winkle W, Anders P, Secor DH, Dixon D (eds) Biology, manage- 
ment, and protection of North American sturgeon. Proc 28th Am Fish Soc Symp. American Fisheries Society, Bethesda, MD, p 211-222

Ireland SC, Beamesderfer RCP, Paragamian VL, Wakkinen VD, Siple JT (2002b) Success of hatchery-reared juvenile white sturgeon (Acipenser transmontanus) following release in the Kootenai River, Idaho, USA. J Appl Ichthyol 18:642-650

Israel JA, Bando KJ, Anderson EC, May B (2009) Polyploid microsatellite data reveal stock complexity among estuarine North American green sturgeon (Acipenser medirostris). Can J Fish Aquat Sci 66:1491-1504

Jarne P, Lagoda PJL (1996) Microsatellites, from molecules to populations and back. Trends Ecol Evol 11:424-429

Jelks HL, Walsh SJ, Burkhead NM, Contreras-Balderas S and others (2008) Conservation status of imperiled North American freshwater and diadromous fishes. Fisheries 33:372-407

> Justice C, Pyper BJ, Beamesderfer RCP, Paragamian VL, Rust PJ, Neufeld MD, Ireland SC (2009) Evidence of density- and size-dependent mortality in hatcheryreared juvenile white sturgeon (Acipenser transmontanus) in the Kootenai River. Can J Fish Aquat Sci 66: 802-815

Kozfkay CC, Campbell MR, Heindel JA, Baker DJ, Kline P, Powell MS, Flagg T (2008) A genetic evaluation of relatedness for broodstock management of captive, endangered Snake River sockeye salmon, Oncorhynchus nerka. Conserv Genet 9:1421-1430

Lacy RC (1997) Importance of genetic variation to the viability of mammalian populations. J Mammal 78:320-335

Lawrence HA, Taylor GA, Millar CD, Lambert DM (2008) High mitochondrial and nuclear genetic diversity in one of the world's most endangered seabirds, the Chatham Island Taiko (Pterodroma magentae). Conserv Genet 9: 1293-1301

Lippé C, Dumont P, Bernatchez L (2006) High genetic diversity and no inbreeding in the endangered copper redhorse, Moxostoma hubbsi (Catostomidae, Pisces): the positive sides of a long generation time. Mol Ecol 15: 1769-1780

Marshall TC, Slate J, Kruuk LEB, Pemberton JM (1998) Statistical confidence for likelihood-based paternity inference in natural populations. Mol Ecol 7:639-655

Meirmans PG, Tienderen PH (2004) GENOTYPE and GENODIVE: two programs for the analysis of genetic diversity of asexual organisms. Mol Ecol Notes 4:792-794

Moyer GR, Rousey JD, Cantrell MA (2009) Genetic evaluation of a conservation hatchery program for reintroduction of the sicklefin redhorse Moxostoma sp. in the Tuckasegee River, North Carolina. N Am J Fish Manag 29: 1438-1443

Editorial responsibility: Steven Cooke, Ottawa, Ontario, Canada
Northcote TC (1973) Some impacts of man on Kootenay Lake and its salmonids. Technical Report No 2. Great Lakes Fishery Commission, Ann Arbor, MI

Paragamian VL, Beamesderfer RCP, Ireland SC (2005) Status, population dynamics, and future prospects of the endangered Kootenai River white sturgeon population with and without hatchery intervention. Trans Am Fish Soc 134:518-532

Parsley MJ, Popoff ND, van der Leuw BK, Wright CD (2008) Seasonal and diel movements of white sturgeon in the lower Columbia River. Trans Am Fish Soc 137:1007-1017

> Peakall R, Smouse PE (2006) GENALEX 6: genetic analysis in Excel. Population genetic software for teaching and research. Mol Ecol Notes 6:288-295

> Pfeiffer T, Roschanski AM, Pannell JR, Korbecka G, Schnittler M (2011) Characterization of microsatellite loci and reliable genotyping in a polyploid plant, Mercurialis perennis (Euphorbiaceae). J Hered 102:479-488

Quattro JM, Greig TW, Coykendall DK, Bowen BW, Baldwin JD (2002) Genetic issues in aquatic species management: the shortnose sturgeon (Acipenser brevirostrum) in the southeastern United States. Conserv Genet 3:155-166

$>$ Rodzen JA, May BP (2002) Inheritance of microsatellite loci in the white sturgeon (Acipenser transmontanus). Genome 45:1064-1076

Rodzen J, Famula TR, May B (2004) Estimation of parentage analysis and relatedness in the polyploid white sturgeon (Acipenser transmontanus) using a dominant marker approach for duplicated microsatellite loci. Aquaculture 232:165-182

> Rourke ML, McPartlan HC, Ingram BA, Taylor AC (2009) Polygamy and low effective population size in a captive Murray cod (Maccullochella peelii peelii) population: genetic implications for wild restocking programs. Mar Freshw Res 60:873-883

> Rourke ML, McPartlan HC, Ingram BA, Taylor AC (2010) Biogeography and life history ameliorate the potentially negative genetic effects of stock on Murray cod (Maccullochella peelii peelii). Mar Freshw Res 61:918-927

Smith TJ, Collins MC, Post WC, McCord JW (2002) Stock enhancement of shortnose sturgeon: a case study. In: Van Winkle W, Anders P, Secor DH, Dixon D (eds) Biology, management, and protection of North American sturgeon. Proc 28th Am Fish Soc Symp. American Fisheries Society, Bethesda, MD, p 31-44

- Waples RS (1999) Dispelling some myths about hatcheries. Fisheries 24:12-21

Zar JH (1999) Biostatistical analysis, 4th edn. Prentice Hall, Upper Saddle River, NJ

> Zhu B, Liao X, Shao Z, Rosenthal H, Chang J (2005) Isolation and characterization of microsatellites in Chinese sturgeon, Acipenser sinensis. Mol Ecol Notes 5:888-892

Submitted: May 24, 2011; Accepted: October 4, 2011

Proofs received from author(s): December 22, 2011 